\title{
Microarray-based analysis of renal complement components reveals a therapeutic target for lupus nephritis
}

\author{
Tao Liu', Mingyue Yang ${ }^{2}$, Ying Xia ${ }^{2}$, Chuan Jiang ${ }^{2}$, Chenxu Li ${ }^{2}$, Zhenyu Jiang ${ }^{1 *}$ and Xiaosong Wang ${ }^{2^{*}}$ (D
}

\begin{abstract}
Background: Screening abnormal pathways and complement components in the kidneys of patients with lupus nephritis (LN) and NZB/W mice may help to identify complement-related therapeutic targets for LN.

Methods: KEGG and GO enrichment assays were used to analyze kidney microarray data of LN patients and NZB/W mice. Immunohistochemistry and immunofluorescence assays were used to measure renal expression of complement-related proteins and TGFß1. Cytokines were measured using RT-qPCR and ELISA.

Results: We screened the renal pathogenic pathways present in LN patients and NZB/W mice and selected the complement activation pathway for further study. The results indicated greater renal expression of C1qa, C1qb, C3, C3aR1, and C5aR1 at the mRNA and protein levels. C3 appeared to be a key factor in LN and the renal signaling downstream of $\mathrm{C} 1$ was inhibited. There were significant correlations between the expression of TGF $\beta 1$ and C3. Analysis of primary cell cultures indicated that TGF $\beta 1$ promoted the expression of C3 and that a TGF $\beta 1$ antagonist decreased the levels of C3 and C3aR. TGF $\beta 1$ inhibition significantly inhibited the deposition of complement-related factors in the kidneys of NZB/W mice.

Conclusions: At the onset of $L N$, there are significant increases in the renal levels of $\mathrm{C} 3$ and other complement pathway-related factors in patients with LN and NZB/W mice. C3 may lead to albuminuria and participate in the pathogenesis of LN. TGF $\beta 1$ promotes C3 synthesis, and TGF $\beta 1$ inhibition may block the progression of LN by inhibiting the synthesis of $\mathrm{C} 3$ and other complement components.
\end{abstract}

Keywords: Lupus nephritis, Complement C3, TGFß1, SB431542, C3aR1

\section{Background}

Lupus nephritis (LN) is one of the most common and serious complications of systemic lupus erythematosus (SLE) [1]. A systematic review reported that 40 to $82 \%$ of Asian patients with SLE had LN [2]. LN is a major cause of renal failure in SLE patients, and it directly increases morbidity and mortality [3]. In-depth investigation of the molecular pathogenesis of LN may provide a

\footnotetext{
* Correspondence: jiangzy@jlu.edu.cn; xiaosongwang@jlu.edu.cn

'Department of Rheumatology and Immunology, The First Hospital of Jilin University, Changchun 130021, China

${ }^{2}$ Department of Translational Medicine, The First Hospital of Jilin University, Changchun 130021, China
}

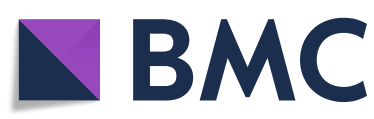

(C) The Author(s). 2021 Open Access This article is licensed under a Creative Commons Attribution 4.0 International License, which permits use, sharing, adaptation, distribution and reproduction in any medium or format, as long as you give appropriate credit to the original author(s) and the source, provide a link to the Creative Commons licence, and indicate if changes were made. The images or other third party material in this article are included in the article's Creative Commons licence, unless indicated otherwise in a credit line to the material. If material is not included in the article's Creative Commons licence and your intended use is not permitted by statutory regulation or exceeds the permitted use, you will need to obtain permission directly from the copyright holder. To view a copy of this licence, visit http://creativecommons.org/licenses/by/4.0/. The Creative Commons Public Domain Dedication waiver (http://creativecommons.org/publicdomain/zero/1.0/) applies to the data made available in this article, unless otherwise stated in a credit line to the data. foundation for more precise therapies. Given the limited availability of sequential biopsies from patients, it remains essential to study informative mouse models of LN. Cross-species analyses can identify genes or pathways that are relevant to human disease and can be further studied in mouse models. Therefore, we initially screened the pathogenic pathways in the kidneys of LN patients and NZB/W mice (a model of LN), and then selected common complement activation pathway for further study.

The in situ deposition of immune complexes from the circulatory system or kidney may promote the 
accumulation of inflammatory cells and cause kidney damage $[4,5]$. Previous studies reported that complement components are produced by the liver, kidneys, brain, blood vessels, and other organs [6, 7]. Renal tubules and podocytes directly produce most of the $\mathrm{C} 3[8$, 9], which is then cleaved into C3a and C3b. Cleavage of C3b by factor I results in the formation of C3c and C3d [10]. C3 plays an important role in the classical, lectinmediated, and alternative immune pathways [11]. C3a is an allergic toxin that stimulates mast cell degranulation after binding to its receptor $\mathrm{C} 3 \mathrm{aR}$, and it also has chemotactic and antimicrobial activities in inflammatory responses [12].

Immunofluorescence studies indicated abundant deposition of TGF $\beta$ and fibrin in the renal tissues of patients with LN [13]. Our previous research found that TGF $\beta 1$ promoted the formation of platelet-derived growth factor subunit B (PDGF-B) [14]. Studies of patients with glomerulonephritis indicated that TGF $\beta 1$ and PDGF-B functioned as important mediators of extracellular matrix (ECM) accumulation, glomerular fibrosis, and mesangial cell proliferation [15-19]. Other research reported that the interaction between TGF $\beta 1$ and different complement components exacerbated epithelial damage in pulmonary fibrosis [20]. However, the relationship of TGF $\beta 1$ with complement components during the pathogenesis of $\mathrm{LN}$ is unclear.

We examined changes in the kidneys of patients with $\mathrm{LN}$ and a mouse model of LN (NZB/W mice). We focused on excessive activation of complement pathways and upregulation of specific complement components such as $\mathrm{C} 3$ that occur during the pathogenesis of $\mathrm{LN}$. We also examined the effect of TGF $\beta 1$ on the expression of $\mathrm{C} 3$ at the mRNA and protein levels, and the effect of a TGF $\beta 1$ inhibitor (SB431542) on the synthesis of C3 and other complement components.

\section{Methods}

\section{Patient data and samples}

Complete clinical data were from SLE patients who were newly diagnosed from July 2018 to December 2019 at the First Hospital of Jilin University (Additional file 1: Supplementary Table S1). All patients had at least 4 of the 11 diagnostic criteria for SLE from the revised criteria of the American College of Rheumatology (ACR) and the American Rheumatology Association [21]. Among these patients with SLE, LN was defined as $24 \mathrm{~h}$ urinary protein of more than $0.5 \mathrm{~g} /$ day or $3+$ on a dipstick test. There were 69 cases of SLE without LN and 76 cases of LN. Blood samples were collected before onset of treatment. Blood samples from 47 healthy persons (control) who were matched for age and sex were also collected. Peripheral blood mononuclear cells (PMBCs) were isolated from whole blood by density gradient centrifugation.

The renal tissues of 23 patients with LN were collected and classified according to the International Society of Nephrology/Renal Pathology (ISN/RPS) 2003 criteria [22]. Renal tissues were also collected from 13 controls; these control tissues were from healthy living donors before kidney transplantation $(n=6)$ or normal kidney tissues distant from the tumors of patients with cancer ( $n$ $=7$ ).

\section{Ethical approval and consent to participate}

Ethical approval for this study was received from the Institutional Medical Ethics Review Board of the First Hospital of Jilin University (reference number: 2017-087). All procedures were in compliance with the Declaration of Helsinki.

\section{Microarray analysis}

Microarray analysis of gene expression profiles was based on data from the GEO database [23]. Kidney tissues were from the whole kidneys of NZB/W mice (accession number: GSE32583) or human glomerular and renal tubular tissues (accession number: GSE32591). Mice were divided into three groups: control (16-weekold NZB/W mice without disease, $n=8$ ); LN1 (23-weekold NZB/W mice with proteinuria and glomerulonephritis, $n=6$ ); and LN2 (36-week-old NZB/W with proteinuria and glomerulonephritis, $n=10$ ). Details are provided at the GEO (https://www.ncbi.nlm.nih.gov/geo/ geo2r/?acc=GSE32583). Samples of human glomeruli and renal tubules were from renal biopsies [23]. The glomerular samples were divided into two groups: CtrlGLO (glomeruli from control living donors, $n=14$ ) and LN-GLO (glomeruli from LN patients, $n=32$ ). Renal tubule samples were divided into two groups: Ctrl-Tub (tubulointerstitium from control living donors, $n=15$ ) and LN-Tub (tubulointerstitium from LN patients, $n=$ 32). Details are provided at the GEO (https://www.ncbi. nlm.nih.gov/geo/geo2r/?acc=GSE32591). The standard of a $p$ value below 0.05 for a fold-change in expression of more than 1.2 was used for differential gene analysis.

\section{Immunohistochemistry and Immunofluorescence staining}

An immunohistochemistry assay was used to examine kidney tissues that were fixed in $10 \%$ neutral formalin solution, embedded in paraffin, and then dewaxed and sliced. After incubation at room temperature with an oxidase blocking solution, animal serum was added, and then a primary antibody against different proteins $(\mathrm{C} 3$, C3aR, C5, C5aR1, C1q, or TGF $\beta 1$; Bioss Biotechnology Co. LTD, Beijing, China) was added for overnight incubation. Then the secondary antibody and hematoxylin were added for visualization. The cell staining score was 
determined using Image J software [24]. The positive ratio of positive cells to total cells was determined by an average of five readings of each sample.

An immunofluorescence assay was used to examine kidney tissues embedded in optimal cutting temperature compound (OCT), frozen, and sectioned. After drying at room temperature, sections were stained with Complement C3 Antibody 11H9 (Cat. \# NB200-540AF594, Novus Biologicals, shanghai, China, Alexa Fluor 594). Sections were then incubated in darkness with $11 \mathrm{H} 9$ $(1.1 \mathrm{mg} / \mathrm{mL}, 1: 200)$ for $1 \mathrm{~h}$ at $37^{\circ} \mathrm{C}$. After washing and drying, $50 \mu \mathrm{L}$ of Hoechst $33342(5 \mathrm{mg} / \mathrm{mL}$, SigmaAldrich, Germany) was added, and the sample was incubated in darkness for $20 \mathrm{~min}$ at $37^{\circ} \mathrm{C}$ for nuclear staining. The sections were then sealed and observed using laser confocal microscopy.

\section{ELISA}

A human complement protein C3 ELISA kit (\#CSBE08665h, Wuhan Huamei, China) was used to measure $\mathrm{C} 3$ according to the manufacturer's instructions. A human TGF $\beta 1$ ELISA kit was used to measure TGF $\beta 1$ in plasma using a previously described procedure [14]. A human TGF $\beta 1$ ELISA kit (\#EK0513, Boster, China) was used to measure TGF $\beta 1$ in urine following the manufacturer's instructions.

\section{Real-time quantitative PCR}

Cells were treated with the TRIzol reagent (Invitrogen, Carlsbad, California, USA), stored at $-80^{\circ} \mathrm{C}\left(5 \times 10^{6}\right.$ cells $/ \mathrm{mL}$ ) for extraction of total RNA, and RT-qPCR was then performed as previously described [14].

\section{Animal experiments}

Female NZB/W mice were purchased from Jackson Laboratory (Bar Harbor, USA). Mice were randomly divided into two groups at the age of 16 weeks. One group received 4 cycles of $200 \mu \mathrm{L}(1.5 \mathrm{mg} / \mathrm{mL})$ intraperitoneal injections of SB431542 and the other group received the same routine with saline. Each treatment cycle consisted of an injection every other day for 1 week, followed by no injections for 3 weeks. The mice were sacrificed at 32 weeks of age, and the kidneys were then harvested for analysis.

\section{Cell culture}

Mouse bone marrow cells were extracted under sterile conditions, and erythrocytes were lysed. Mouse bone marrow cells were cultured using DMEM with penicillin $(100 \mathrm{U} / \mathrm{mL})$, streptomycin $(100 \mu \mathrm{g} / \mathrm{mL})$, and $10 \% \mathrm{FBS}$. These cells were divided into three groups: control, mouse recombinant TGF $\beta 1(2.5 \mathrm{ng} / \mathrm{mL}$ R\&D Systems, Minneapolis, MN, USA), and SB431542 (5 $\mu$ M; SigmaAldrich, St. Louis, MO, USA).
Mouse fresh kidney samples were fully shredded to a size of $1 \mathrm{~mm}^{3}$ using ophthalmic scissors. A type I collagenase solution $(0.1 \mathrm{U} / \mathrm{mL})$ was added, followed by shaking for $60 \mathrm{~min}$ at $37^{\circ} \mathrm{C}$. Single primary renal cells were obtained by filtration and cultured in RPMI1640 with medium penicillin $(100 \mathrm{U} / \mathrm{mL})$, streptomycin $(100 \mu \mathrm{g} /$ $\mathrm{mL}$ ), and $10 \%$ FBS. The cells were divided into three groups: control, mouse recombinant TGF $\beta 1(2.5 \mathrm{ng} / \mathrm{mL})$, and SB431542 $(5 \mu \mathrm{M})$.

Human PBMCs were cultured in RPMI 1640 medium with penicillin $(100 \mathrm{U} / \mathrm{mL})$, streptomycin $(100 \mu \mathrm{g} / \mathrm{mL})$, and patient plasma (9:1 ratio of RPMI 1640: plasma). The cultured cells were divided into three groups: control; human recombinant TGF $\beta 1(7.5 \mathrm{ng} / \mathrm{mL}, \mathrm{R} \& D$ Systems, Minneapolis, MN, USA); and SB431542 $(5 \mu \mathrm{M})$.

All cells were collected after culturing in an incubator $\left(37^{\circ} \mathrm{C}\right.$ and $5 \% \mathrm{CO}_{2}$ ) for $5 \mathrm{~h}$.

\section{Statistical methods}

GraphPad Prism version 8.0 (San Diego CA, USA) was used for statistical analysis and production of figures. To compare different matrices, all data between the maximum (red) and minimum (blue) values for each gene expression level were used to generate an unsupervised heat map. The Wilcoxon signed-rank test was used to compare paired samples, the Mann-Whitney U test was used to compare unpaired samples, and the nonparametric Spearman rank correlation test was used to determine correlations. A $p$ value below 0.05 was considered significant.

\section{Results}

Activation of complement pathways and upregulation of complement components in kidneys of patients with LN

Our initial microarray analysis compared renal tissue samples from healthy controls and patients with $\mathrm{LN}$ and identified the presence of 4754 differentially expressed genes, with 2632 upregulated genes and 2122 downregulated genes in the glomeruli of LN patients. (Additional file 2: Supplementary Figure S1). A similar analysis indicated there were 3725 differentially expressed genes in the renal tubules, with 2359 upregulated genes and 1366 downregulated genes in the renal tubules of LN patients (Additional file 2: Supplementary Figure S1).

KEGG enrichment analysis indicated there were 89 significantly upregulated pathways in LN patients (Additional file 3: Supplementary Figure S2). We also compared the differentially regulated pathways in LN patients and model mice, to identify pathways that were altered in both (Fig. 1A). These pathways included NFkappa B signaling pathway, B cell receptor signaling pathway, Toll-like receptor signaling pathway, complement and coagulation cascades, $\mathrm{T}$ cell receptor signaling 


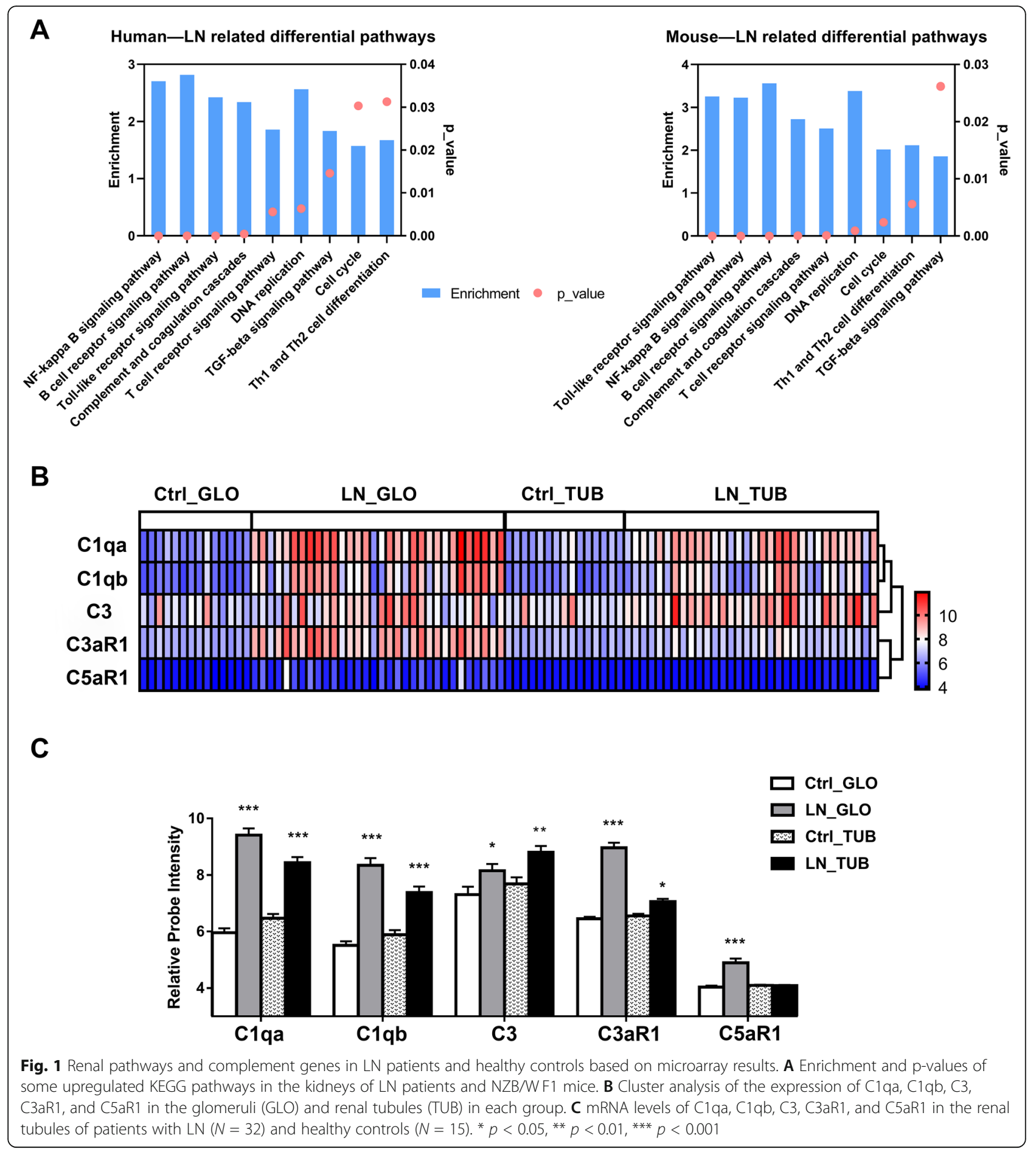

pathway, TGF $\beta$ signaling pathway, and several other pathways (Additional file 4: Supplementary Table S2).

Cluster analysis showed close similarities in the expression of C1qa with $\mathrm{C} 1 \mathrm{qb}$, of C3aR1 with C5aR1, and of $\mathrm{C} 3$ with $\mathrm{C} 1 \mathrm{qa}$ and $\mathrm{C} 1 \mathrm{qb}$ (Fig. 1A). Quantitation of these microarray data (Fig. 1B) indicated that LN patients had increased expression of C1qa, C1qb, C3,
C3aR1, and C5aR1 in glomeruli, and increased expression of all these mRNAs except C5aR1 in renal tubules.

Next, we performed immunohistochemical analysis of the kidneys of LN patients and healthy controls. The results indicated greater protein levels of C1q, C3, C5, C3aR, C5aR1, and CR3 in the renal tubules of patients with LN (Fig. 2A). Quantitation of expression using cell 


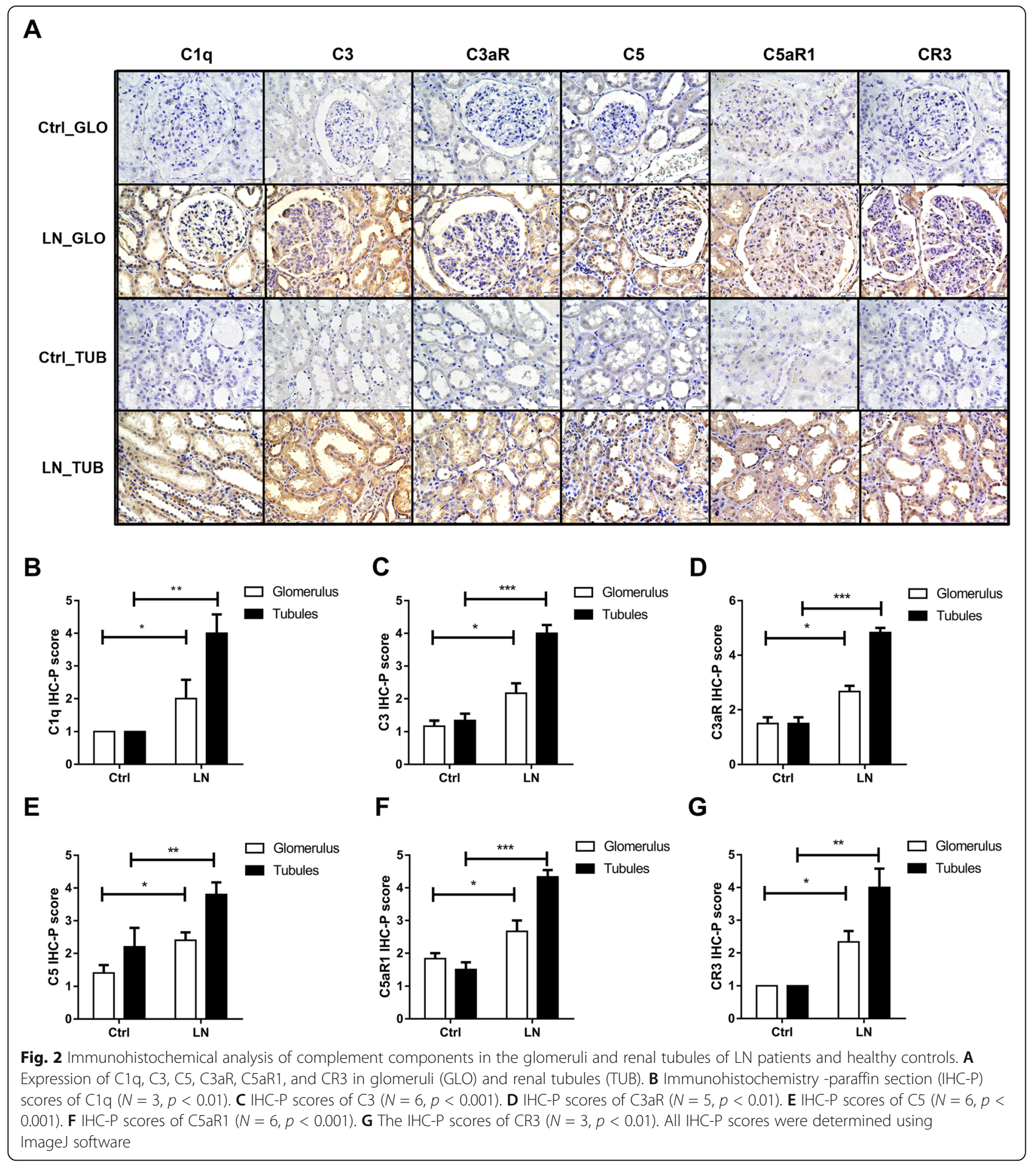

staining scores from Image $J$ software confirmed that these results were significantly different in the renal tubules and glomeruli (Fig. 2B-G). These results suggested that the increased protein levels in the kidneys of patients with LN may be related to over-activation of complement pathways.
Activation of complement pathways and upregulation of complement components in kidneys of NZB/W mice

We further analyzed the kidneys of NZB/W mice. A comparison of whole kidney tissues before and at earlystage disease indicated 1725 differentially expressed genes, with 1375 upregulated genes and 350 
downregulated genes in mice with early-stage disease (Additional file 2: Supplementary Figure S1). A comparison of whole kidney tissues before and at late-stage disease indicated 7966 differentially expressed genes, with 2863 upregulated genes and 5103 downregulated genes in the mice with late-stage disease (Additional file 2: Supplementary Figure S1).

Cluster analysis of complement-related factors in these mice indicated that the expression of $\mathrm{C} 1 \mathrm{qa}, \mathrm{C} 1 \mathrm{qb}, \mathrm{C} 1 \mathrm{qc}$, C3, C3aR1, C5aR1, CR3, and CR4 in NZB/W mice gradually increased during disease progression (Fig. 3A). These changes had some similarities to those in human glomeruli and renal tubules. In particular, the expression of C1qa and C1qb clustered together (as in humans), the expression of $\mathrm{C} 1 \mathrm{qc}$ and $\mathrm{C} 3 \mathrm{aR} 1$ clustered together. However, the expression of $\mathrm{C} 3$ clustered with $\mathrm{C} 5 \mathrm{aR} 1$, and the expression pattern of $\mathrm{C} 3 \mathrm{aR} 1$ was similar to $\mathrm{C} 1 \mathrm{qa}, \mathrm{C} 1 \mathrm{qb}$, and C1qc.

Quantitation of the microarray data (Fig. 3B) indicated progressively increased expression of $\mathrm{C} 1 \mathrm{qa}, \mathrm{C} 1 \mathrm{qb}, \mathrm{C} 1 \mathrm{qc}$, C3, C3aR1, C5aR1, CR3, and CR4 as the disease progressed. In particular, C3 mRNA had significantly greater expression at late-stage disease than early-stage disease.

We also performed immunohistochemical analysis of $\mathrm{C} 3$ and $\mathrm{C} 3 \mathrm{aR}$ in the kidneys of five NZB/W mice. The results indicated increasing deposition of both proteins as the disease progressed (Fig. 3C). These results confirmed that changes in complement components were associated with the pathogenesis of LN in this mouse model.

To identify the upstream and downstream relationships of these upregulated genes (C1q, C3, C3aR1, C5aR1, CR3, and CR4), we performed KEGG pathway analysis using the lupus mouse microarray database (Fig. 3D). The starting component C1qrs activates the downstream complement $\mathrm{C} 3$, which is then cleaved into two downstream factors-C3a and C3b. The binding of different complements to their receptors (C3aR1, C5aR1, CR3, etc.), induces responses, including phagocytosis, degranulation, and chemotaxis. We found significant upregulation of C1q, C3, CR3, CR4, C3aR1, and C5aR1. We also found upregulation of C1INH (also known as SERPING1), which is known to inhibit downstream signaling of the classical and lectin pathways. These results confirmed changes in the levels of different complement components function in the pathogenesis of LN.

\section{Complement related upregulated GO terms and C3 levels in $\mathrm{LN}$ patients}

GO enrichment analysis of biological process class help us to explore the biological functions of the differentially expressed genes. We chose the immune response related complement and coagulation cascades pathway for further study. The complement related upregulated genes were depicted as directed acyclic graphs in Fig. 4A. The detailed information of the significantly increased complement-related GO terms was listed in Table 1 . The results indicated significantly upregulated genes, including serpin family G member 1 (SERPING1) and alpha-2-macroglobulin (A2M), which were significantly enriched in the GO term of negative regulation of complement activation, lectin pathway (GO: 0001869) in the kidneys of LN patients and NZB/W mice. This result suggests inhibition of downstream signaling of $\mathrm{C} 1$ in the kidneys of LN patients. The significantly upregulated genes including formyl peptide receptor 1 (FPR1), formyl peptide receptor 2 (FPR2), and complement C3a receptor 1 (C3aR1) were significantly enriched in the GO term of complement receptor-mediated signaling pathway (GO: 0002430) in the kidneys of LN patients and $\mathrm{NZB} / \mathrm{W}$ mice. This result suggests that C3a may be a key pathogenic factor in LN patients. Upregulation of the term of regulation of complement activation (GO: 0030449) was significant only in LN patients, and upregulation of the term of complement activation, alternative pathway (GO: 0006957) was significant only in NZB/W mice.

To further examine the possible role of $\mathrm{C} 3$ in the pathogenesis of $\mathrm{LN}$, we examined the expression of $\mathrm{C} 3$ in the urine, blood, and kidney tissues of LN patients. The results indicated the LN group had a significantly higher urinary level of $\mathrm{C} 3$ than the healthy controls and the SLE without LN group (both $p<0.001$; Fig. 4B). However, the plasma of the LN group had a decreased level of C3 ( $p<0.001$; Fig. 4C) relative to the SLE without the LN group. This suggests that C3 was excreted from the kidneys of patients with LN. The plasma of the LN group also had a lower level of C1q than the SLE without the LN group ( $p<0.05$; Additional file 5: Supplementary Figure S3A), but these groups had no significant difference in the level of $\mathrm{C} 4$ ( $\mathrm{p}>0.05$; Additional file 5: Supplementary Figure S3B). We also observed significant correlations of the plasma levels of $\mathrm{C} 3$ with $\mathrm{C} 1 \mathrm{q}$ $(p<0.0001, r=0.6345$; Figure S3 C) and with C4 $(p<$ $0.0001, r=0.5261$; Figure S3D). These results suggest that an elevated level of C3 may contribute to the pathogenesis of LN and proteinuria. Our immunohistochemistry analysis indicated that the expression of $\mathrm{C} 3$ was similar in LN patients with class IV, V, and IV+V disease, but the expression was greater in those with class III disease than healthy controls (Additional file 6: Supplementary Figure S4).

Upregulation of TGF $\beta 1$ and $C 3$ during pathogenesis of $L N$ We previously reported a correlation between the levels of TGF $\beta 1$ and C3 in whole blood cells of SLE patients [25] and proposed that the levels of TGF $\beta 1$ and C3 may 


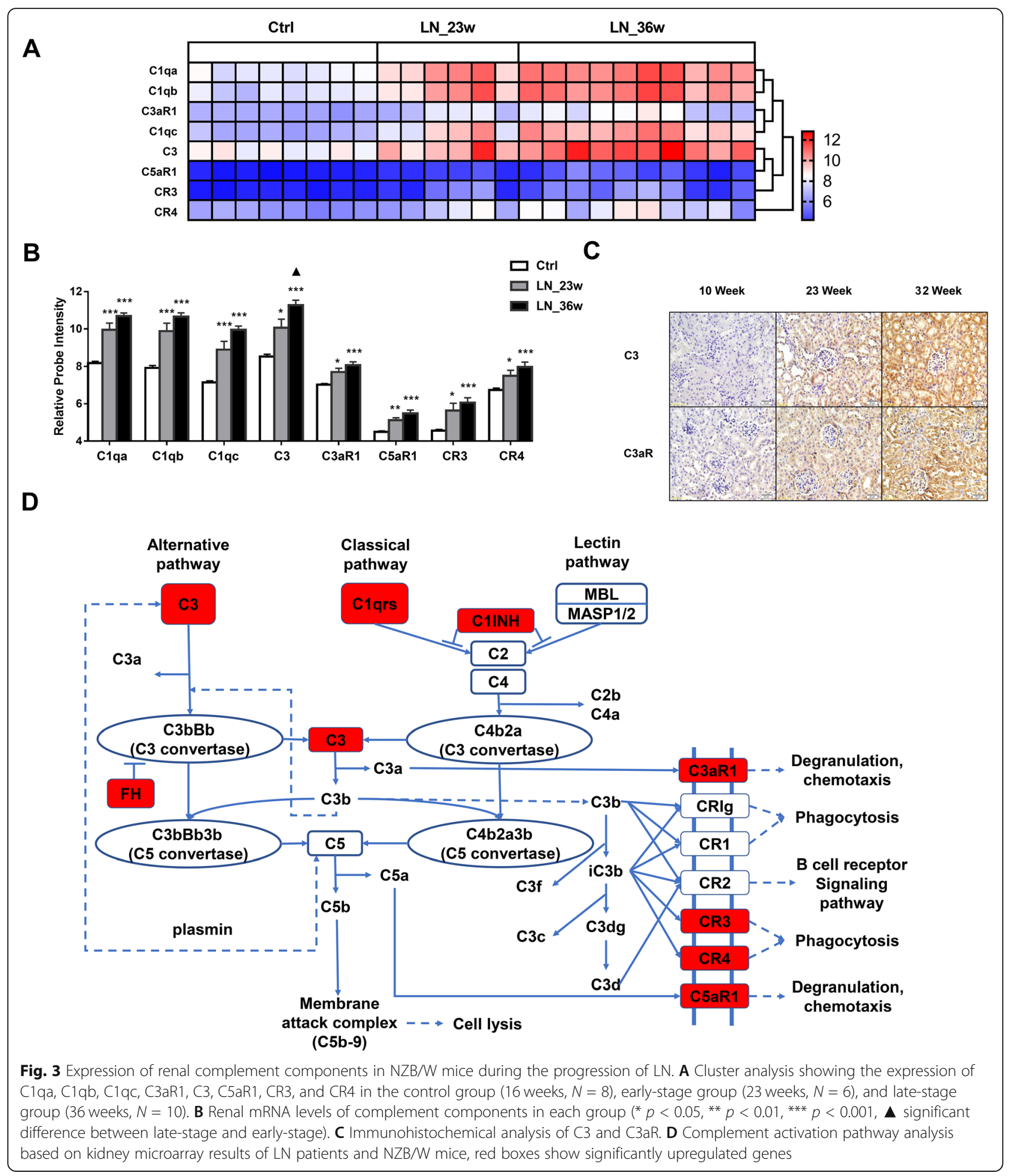

have similar changes in the urine and blood of patients with LN. Our analysis of plasma in the LN group indicated a decreased level of TGF $\beta 1$ relative to the SLE without the LN group ( $p<0.05$; Fig. $5 \mathrm{~A})$. Our measurements of TGF $\beta 1$ and $\mathrm{C} 3$ in patients with $\mathrm{LN}$ indicated positive correlations in the levels of these proteins $(p=$
0.0150, $r=0.3916$; Fig. 5B) and mRNAs $(p=0.0014, r=$ 0.6949; Fig. 5C) in blood. However, the LN group had a significantly higher urinary level of TGF $\beta 1$ than the SLE without the LN group $(p<0.001$; Fig. 5D). Analysis of the relationship between urinary TGF $\beta 1$ and $24 \mathrm{~h}$ urinary protein indicated a significantly positive correlation 


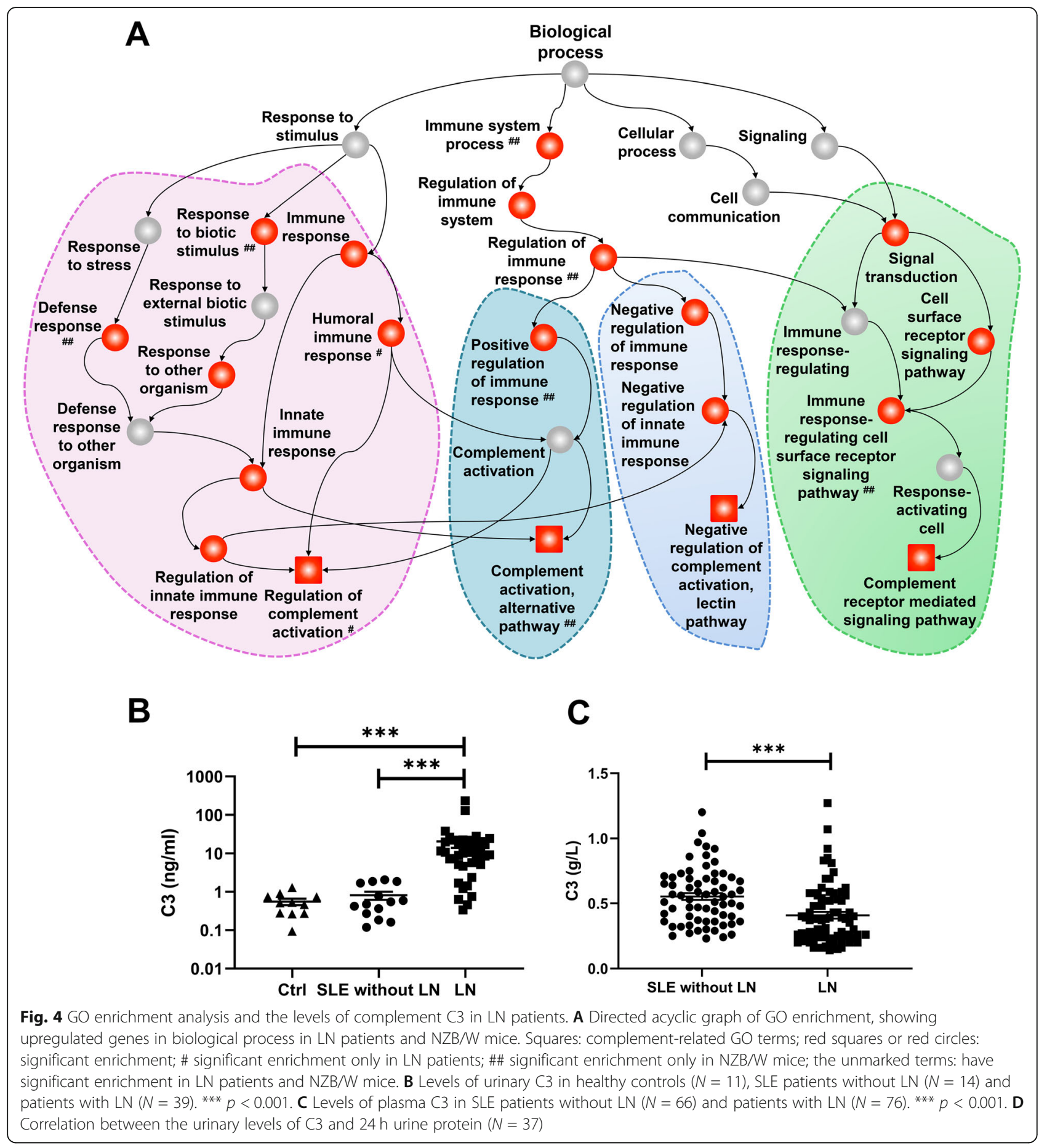

( $p<0.0001, r=0.7120$; Fig. 5E). In addition, the levels of TGF $\beta 1$ were significantly correlated with that of C3 in the urine of these patients $(p=0.0054, r=0.5115$; Fig. 5F). Our renal immunohistochemistry results (Fig. 5G) also indicated a correlation of cell staining scores for TGF $\beta 1$ and C3 ( $p=0.0149, r=0.7714$; Fig. $5 \mathrm{H})$. These findings suggest that TGF $\beta 1$ and $\mathrm{C} 3$ function in the pathogenesis of LN.

\section{TGF $\beta 1$ upregulates $\mathrm{C} 3$}

To confirm that TGF $\beta 1$ regulates the expression of $\mathrm{C} 3$, we cultured NZB/W mouse bone marrow cells with TGF $\beta 1$ or SB431542. The results indicated that TGF $\beta 1$ significantly increased the expression of C3 mRNA $(p<$ 0.001; Fig. 6A) and that SB431542 significantly decreased the expression of this mRNA ( $p<0.01$; Fig. 6A). Interestingly, SB431542 also decreased the level of C3aR1 
Table 1 Details of the four significantly different GO terms associated with complement

\begin{tabular}{|c|c|c|c|c|c|c|c|c|c|}
\hline Species & GO_ID & GO_Name & $\begin{array}{l}\text { Population_- } \\
\text { mapped_id }\end{array}$ & $\begin{array}{l}\text { Study__ } \\
\text { mapped } \\
\text { id }\end{array}$ & $\begin{array}{l}\text { Gene_- } \\
\text { symbol }\end{array}$ & Description & Enrichment & $\begin{array}{l}p \\
\text { value }\end{array}$ & FDR \\
\hline Human & $\begin{array}{l}\text { GO: } \\
0001869\end{array}$ & $\begin{array}{l}\text { Negative } \\
\text { regulation of } \\
\text { complement } \\
\text { activation, lectin } \\
\text { pathway }\end{array}$ & 2 & 2 & $\begin{array}{l}\text { SERPING1, } \\
\text { A2M }\end{array}$ & $\begin{array}{l}\text { Serpin family G member 1, alpha-2- } \\
\text { macroglobulin }\end{array}$ & 14.158 & 0.005 & 0.062 \\
\hline Mouse & $\begin{array}{l}\text { GO: } \\
0001869\end{array}$ & $\begin{array}{l}\text { Negative } \\
\text { regulation of } \\
\text { complement } \\
\text { activation, lectin } \\
\text { pathway }\end{array}$ & 2 & 2 & $\begin{array}{l}\text { Serping1, } \\
\text { A2m }\end{array}$ & $\begin{array}{l}\text { Serine (or cysteine) peptidase inhibitor, } \\
\text { clade G, member 1, alpha-2- } \\
\text { macroglobulin }\end{array}$ & 21.701 & 0.002 & 0.019 \\
\hline Human & $\begin{array}{l}\text { GO: } \\
0002430\end{array}$ & $\begin{array}{l}\text { Complement } \\
\text { receptor- } \\
\text { mediated signal- } \\
\text { ing pathway }\end{array}$ & 9 & 3 & $\begin{array}{l}\text { FPR1, FPR2, } \\
\text { C3AR1 }\end{array}$ & $\begin{array}{l}\text { Formyl peptide receptor 1, formyl } \\
\text { peptide receptor 2, complement C3a } \\
\text { receptor } 1\end{array}$ & 4.719 & 0.021 & 0.153 \\
\hline Mouse & $\begin{array}{l}\text { GO: } \\
0002430\end{array}$ & $\begin{array}{l}\text { Complement } \\
\text { receptor- } \\
\text { mediated signal- } \\
\text { ing pathway }\end{array}$ & 11 & 4 & $\begin{array}{l}\text { Fpr1, C3ar1, } \\
\text { Fpr2, C5ar1 }\end{array}$ & $\begin{array}{l}\text { Formyl peptide receptor } 1 \text {, complement } \\
\text { component } 3 \text { a receptor } 1 \text {, formyl } \\
\text { peptide receptor } 2 \text {, complement } \\
\text { component } 5 \text { a receptor } 1\end{array}$ & 7.891 & 0.001 & 0.013 \\
\hline Human & $\begin{array}{l}\text { GO: } \\
0030449\end{array}$ & $\begin{array}{l}\text { Regulation of } \\
\text { complement } \\
\text { activation }\end{array}$ & 29 & 7 & $\begin{array}{l}\text { C5AR1, C3, } \\
\text { C3AR1, } \\
\text { C1QBP, } \\
\text { CFH, CFP, } \\
\text { PROS1 }\end{array}$ & $\begin{array}{l}\text { Complement } \mathrm{C} 5 \text { a receptor } 1 \text {, } \\
\text { complement } \mathrm{C} 3 \text {, complement } \mathrm{C} 3 \mathrm{a} \\
\text { receptor } 1 \text {, complement } \mathrm{C} 1 \mathrm{q} \text { binding } \\
\text { protein, complement factor } \mathrm{H} \text {, } \\
\text { complement factor properdin, protein } \mathrm{S} \\
\text { (alpha) }\end{array}$ & 3.417 & 0.003 & 0.052 \\
\hline Mouse & $\begin{array}{l}\text { GO: } \\
0006957\end{array}$ & $\begin{array}{l}\text { Complement } \\
\text { activation, } \\
\text { alternative } \\
\text { pathway }\end{array}$ & 10 & 3 & C3, Cfh, Cfp & $\begin{array}{l}\text { Complement component } 3 \text {, } \\
\text { complement component factor } \mathrm{h} \text {, } \\
\text { complement factor properdin }\end{array}$ & 6.510 & 0.009 & 0.055 \\
\hline
\end{tabular}

mRNA ( $p<0.001$; Fig. 6A), although TGF $\beta 1$ had no significant effect on this mRNA ( $p>0.05$; Fig. 6A). TGF $\beta 1$ and SB431542 had no significant effects on the level of C1q mRNA ( $p>0.05$; Fig. 6A).

We used the same method to culture NZB/W mouse kidney primary cells. The results showed that SB431542 decreased the mRNA levels of C3 ( $p<0.05$; Fig. 6B) and C3aR1 ( $p<0.001$; Fig. 6B), although TGF $\beta 1$ had no significant effect on these mRNAs (both $p>0.05$; Fig. 6B). TGF $\beta 1$ and SB431542 also had no significant effect on C1q mRNA ( $p>0.05$; Fig. 6B).

We performed similar experiments using the PBMCs from SLE patients. TGF $\beta 1$ and SB431542 had the same effects on C3 mRNA (both $p<0.01$; Fig. 6C). However, analysis of C3aR1 indicated that TGF $\beta 1$ and SB431542 had no significant effect relative to the controls, although expression of C3aR1 mRNA was greater in cells given TGF $\beta 1$ than SB431542 ( $p<0.05$; Fig. 6 C). TGF $\beta 1$ and SB431542 had no significant effect on C1q mRNA (both $p>0.05$; Fig. 6C).

We also tested the effect of 3 months of administration of SB431542 or saline on NZB/W mice. The results indicated that SB431542 significantly reduced the levels of C1q, C3, C5, C3aR, C5aR1, and CR3 (Fig. 6D). To confirm these results, we performed immunofluorescence staining of C3 using a different antibody. These results also indicated that SB431542 significantly reduced the levels of C3 (Fig. 6E).

\section{Discussion}

We screened and analyzed the kidney genomic data of $\mathrm{LN}$ patients and NZB/W mice, to identify pathways related to the pathogenesis of this disease, with a focus on complement activation. Our results indicated the activation of various complement-related factors and GO terms, and subsequent analysis suggested they had roles in the pathogenesis of LN. In particular, the results suggested that C3 was a key factor in LN and the signaling downstream of $\mathrm{C} 1 \mathrm{q}$ was inhibited in the kidneys of patients with this disease. TGF $\beta 1$ was associated with an increased level of C3 in NZB/W mice and LN patients, but was unrelated to C1q. A TGF 1 inhibitor (SB431542) significantly inhibited C3 synthesis in primary kidney cells and peripheral blood cells and reduced the complement deposition in the kidneys of NZB/W mice.

To provide foundation for the more effective treatment of LN, we identified pathways that had differential 


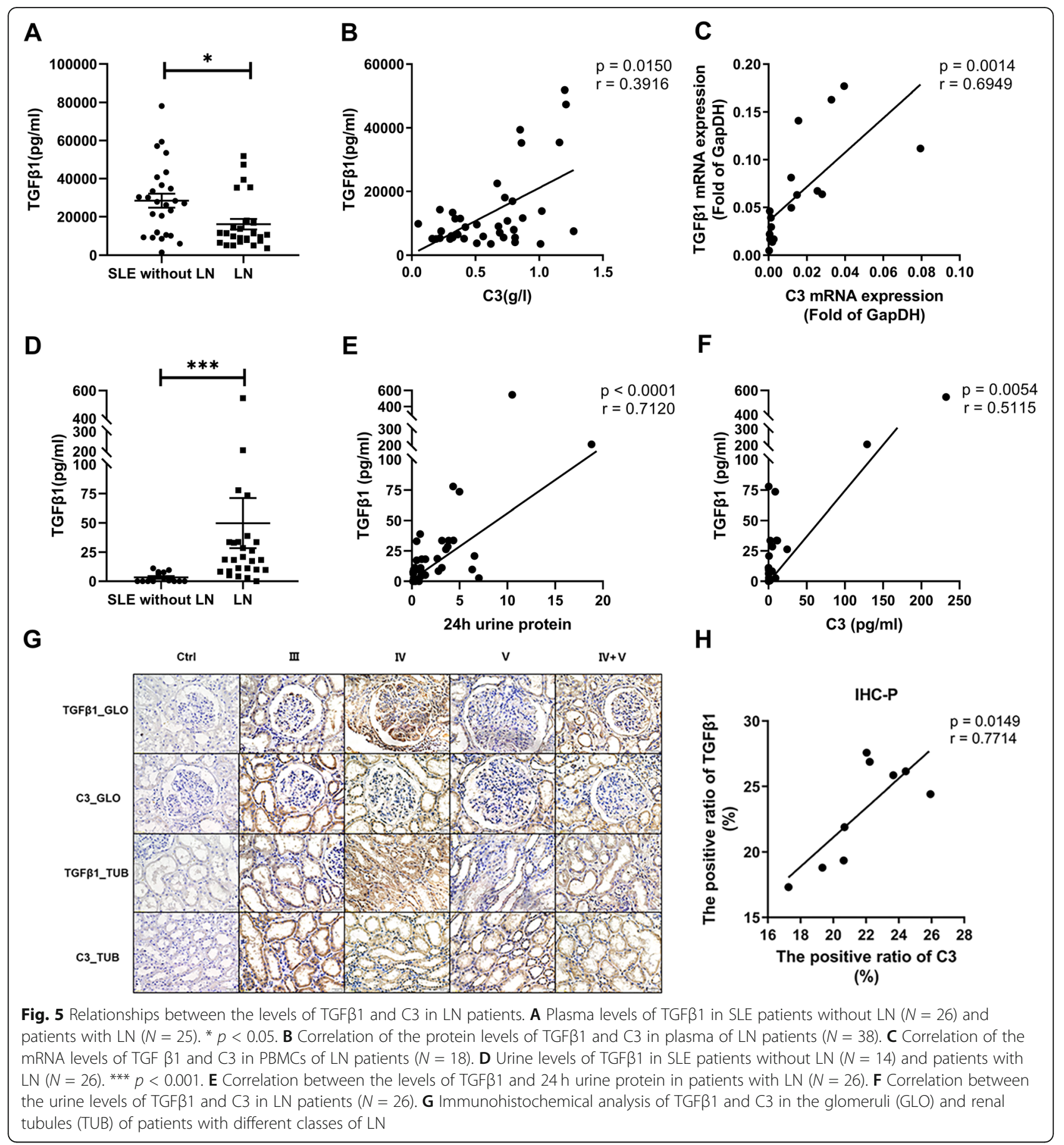

expression in LN patients and model mice, relative to controls. We also used bioinformatics to analyze mRNA expression of complement-related factors in the kidney tissues of LN patients and NZB/W mice. KEGG enrichment analysis showed similarities in differential expression pathways of complement and coagulation cascades in LN patients and NZB/W mice. The present study is the first to use big data from microarray analysis to demonstrate that the mRNA levels of multiple complements (C1qa, C1qb, C3) and complement receptors (C3aR1 and C5aR1) were upregulated in the glomeruli and renal tubules of patients with $\mathrm{LN}$ and the results were generally similar in the kidney tissues of $\mathrm{NZB} / \mathrm{W}$ mice. Moreover, as the disease progressed in these mice, the levels of $\mathrm{C} 3$ and $\mathrm{C} 1 \mathrm{q}$ (C1qa, C1qb, C1qc), C3, C3aR, C5aR1, CR3, and CR4 continued to increase. We confirmed the deposition of complementrelated factors including $\mathrm{C} 1 \mathrm{q}, \mathrm{C} 3, \mathrm{C} 3 \mathrm{aR}, \mathrm{C} 5$, and CR3 by 
A

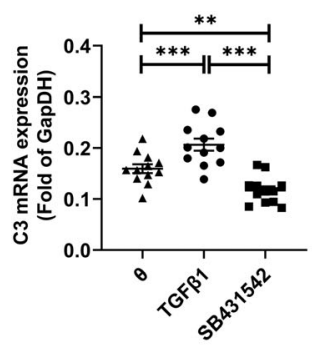

B

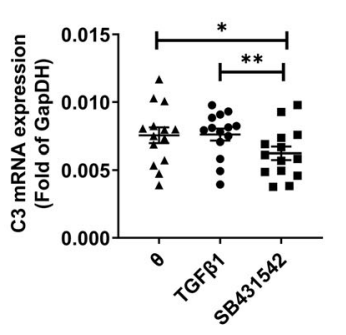

C

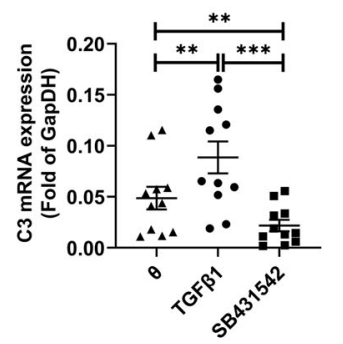

Mouse_BM
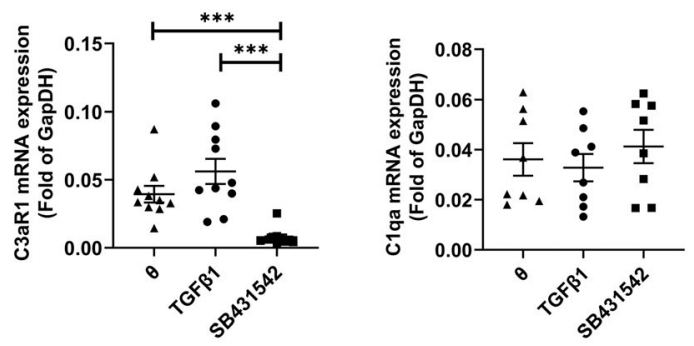

Mouse_Kidney
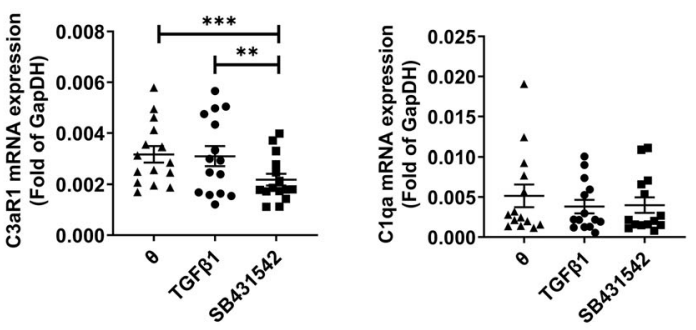

Human_PBMC
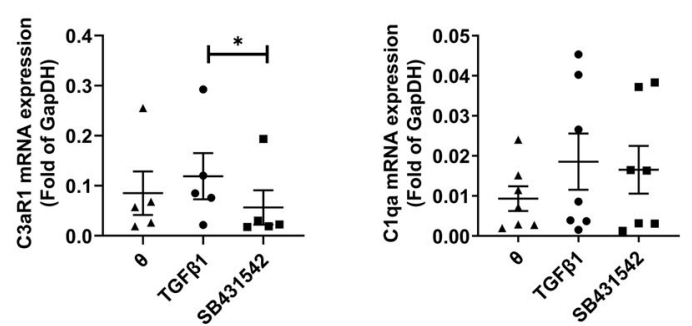

D

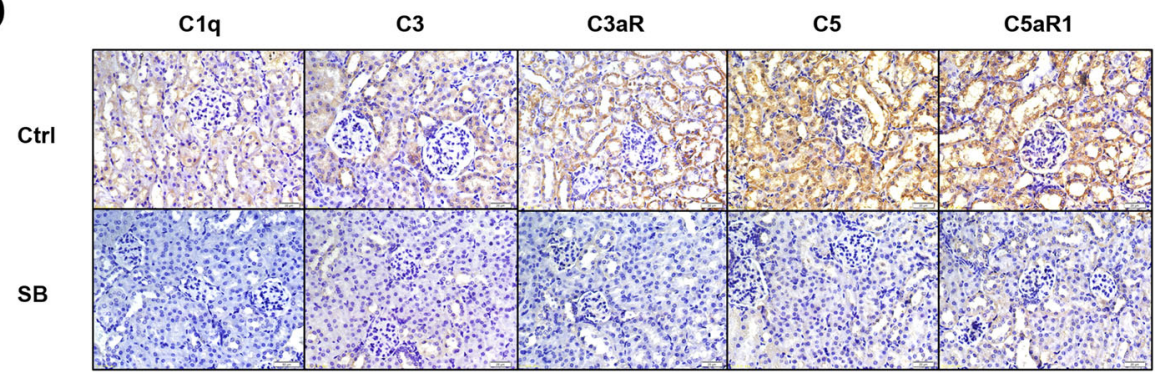

E

32w Ctrl

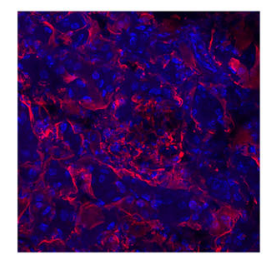

$32 w$ SB

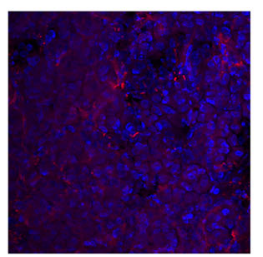

$8 w$

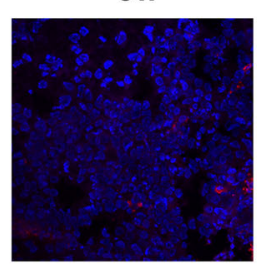


(See figure on previous page.)

Fig. 6 Effects of TGF $\beta 1$ on the production of C3 and other complement components. A mRNA levels of C3 $(N=12)$, C3AR1 ( $N=10)$, and C1qa $(N=8)$ in the presence of TGFB1 or SB431542 in bone marrow cell-cultures of NZB/W mice. B mRNA levels of C3 $(N=14), C 3 a R 1(N=15)$, and C1qa $(N=14)$ in the presence of TGF $\beta 1$ or SB431542 in kidney primary cell-cultures of NZB/W mice. $C$ mRNA levels of C3 $(N=11)$, C3AR1 $(N=5)$, and $\mathrm{C1}$ qa $(N=7)$ in the presence of TGF $\beta 1$ or SB431542 in PBMC-cultures of LN patients. ${ }^{*} p<0.05,{ }^{* *} p<0.01,{ }^{* * *} p<0.001$. D

Immunohistochemical analysis of C1q, C3, C5, and their receptors (C3aR, C5aR1) in the kidneys of NZB/W mice treated with SB431542 or saline as control. E Immunofluorescence analysis of C3 in the kidney of NZB/W mice: 32-week-old mice treated with SB431542, 32-week-old mice treated with saline, and 8-week-old mice without treatment. Red fluorescence indicates C3 and blue fluorescence indicates nuclei

immunohistochemistry in the kidneys of LN patients. Further analysis of mice indicated significant upregulation of C1q mRNA (an upstream component) as well as C3 and its receptors C3aR1, CR3, and CR4 (downstream components). Therefore, there is upregulation of numerous complement-related factors and pathways in the kidneys of LN patients.

Previous studies on mouse models of lupus (NZB/W and MRL/lpr mice) reported increased renal expression of complement mRNAs and proteins [26, 27]. Moreover, complement inhibitors reduced proteinuria and prevented the deterioration of renal function in these animal models [26, 27]. Excessive activation of the renal complement system can cause renal tubular interstitial cytotoxicity, in which renal tubular epithelial cells are a key target of C3, resulting in proteinuria and promotion of renal fibrosis [28-30]. These previous results are consistent with our results, and taken together confirm the presence of complement pathway activation in the kidneys of patients with $\mathrm{LN}$.

Our GO enrichment analysis showed the presence of an activated immune response cascade. The upregulated FPR1, FPR2, and C3aR1 were significantly enriched in the GO term of complement receptor-mediated signaling pathway in the kidneys of LN patients and NZB/W mice. FPR1 and FPR2 are Gi-protein-coupled receptors that are expressed mainly by mammalian phagocytic leukocytes; FPRs are involved in antibacterial host defense and inflammation; C3aR1 is a receptor for the chemotactic and inflammatory peptide anaphylatoxin C3a. Our results suggest that $\mathrm{C} 3$ is a key pathogenic factor in the kidneys of LN patients. C3 functions as the core of the three pathways of complement system activation, and forms a C5b-9 membrane attack complex that attacks kidney tissues via a cascade reaction [31]. This leads to the release of proinflammatory mediators and other factors (e.g., reactive oxygen species and tissue degrading proteases) that damage the surfaces of endothelial cells and the glomerular basement membrane, destroy glomerular podocyte foot processes, and disrupt kidney filtration, ultimately leading to proteinuria, kidney tissue damage, and then LN [31].

We found that the reduced blood level of $\mathrm{C} 3$ in patients with LN was associated with an increased level of C3 in their urine. Liu et al. [32] reported that a lower serum level of C3 was associated with a higher risk of focal segmental glomerulosclerosis and end-stage renal disease. Our results also indicated that NZB/W mice had an increasing renal expression of $\mathrm{C} 3$ and $\mathrm{C} 3 \mathrm{aR}$ as the disease progressed. This is consistent with previous reports on the deposition of large amounts of C3 in the kidneys of patients with $\mathrm{LN}$ and in mouse models of this disease [33, 34]. Our finding of a significant decrease of plasma C3 in the presence of LN is consistent with previous clinical and animal experiments which reported that complement activation leads to secondary decreases in the blood levels of $\mathrm{C} 4$ and $\mathrm{C} 3$ during the active period of SLE [35]. We speculate that the loss of C3 through urine and deposition in the kidneys were partly responsible for the decreased plasma level of C3 in LN.

Elevated urinary protein is an important diagnostic indicator of LN. Previous research found that the increased level of complement in the urine of patients with LN was related to the overall increased level of urinary protein [36]. We found that complement components C3aR and C5aR1 were significantly upregulated in the kidneys of LN patients and NZB/W mice. In fact, there is evidence that $\mathrm{C} 3 \mathrm{a}$ and $\mathrm{C} 5 \mathrm{a}$ are powerful chemoattractants that guide neutrophils, monocytes, and macrophages to the site of complement activation, and thus promote inflammation [37]. Studies of the kidney tissues of patients reported upregulation of $\mathrm{C} 3 \mathrm{aR}$ and $\mathrm{C} 5 \mathrm{aR}$ at the mRNA and protein levels, and that C3aR or C5aR antagonists reduced the symptoms of LN [26, 27, 38].

We found that the levels of $\mathrm{C} 1 \mathrm{q}$ and $\mathrm{C} 4$ were positively correlated with the blood level of C3. As an upstream factor, C1q activates $\mathrm{C} 3$ with the help of $\mathrm{C} 4$ in the classical complement pathway. However, our GO analysis showed that upregulated SERPING1 and A2M were significantly enriched in the GO term of negative regulation of complement activation lectin pathway in the kidneys of LN patients and NZB/W mice. This result suggests that the downstream signaling of $\mathrm{Clq}$ is significantly inhibited by SERPING1 and A2M in the kidneys of these patients. C1q mediates a variety of immunoregulatory functions that are considered important in the prevention of autoimmunity, such as enhancement of phagocytosis and regulation of cytokine production by antigen-presenting cells [39]. A deficiency of C1q 
strongly predisposes individuals to SLE [40], which is thought to be related to the role of $\mathrm{C} 1 \mathrm{q}$ in the removal of apoptotic cells [41] and the clearance of immune complex [42]. The lupus autoantigen on the surface of apoptotic cells appears to stimulate an inappropriate immune response in SLE [43-45]. Decreased serum levels of $\mathrm{C} 1 \mathrm{q}$ protein and increased titers of $\mathrm{C} 1 \mathrm{q}$ antibodies may be involved in the pathogenesis of SLE, especially LN [46]. The prognosis of LN patients is poor when there is no C1q deposition in the kidneys [47]. Taken together, these results support the conclusions that $\mathrm{C} 3$ is a key pathogenic factor in the kidneys of LN patients and that the downstream signaling of $\mathrm{C} 1$ is inhibited in the kidneys of these patients.

We searched for a factor other than $\mathrm{C} 1$, that could potentially regulate complement $\mathrm{C} 3$ in $\mathrm{LN}$ patients. The results indicated that $\mathrm{LN}$ patients had a decreased plasma level of TGF $\beta 1$, but the urinal level was increased. The urinary level of TGF $\beta 1$ also had a positive correlation with the level of total urinary protein. Our analysis of the peripheral blood and kidney tissues of patients with LN indicated a correlation in the levels of TGF $\beta 1$ and $\mathrm{C} 3$ at the mRNA and protein levels. In addition, our primary cells-cultures indicated that TGF $\beta 1$ promoted the expression of $\mathrm{C} 3$ and that a TGF $\beta 1$ antagonist (SB431542) decreased the levels of $\mathrm{C} 3$ and C3aR. In agreement, other researchers found that TGF $\beta 1$ modulated C3 in cultured human monocytes [48] and another research group observed that the serum TGF $\beta 1$ level had positive correlations with eGFR, C3, and C4 in SLE patients [49]. Therefore, the data presented here support the interpretation that TGF $\beta 1$ modulates $\mathrm{C} 3$, and they both function in the pathogenesis of LN.

Many previous studies examined the effect of TGF $\beta 1$ inhibition as treatment for various diseases. For example, clinical trials of systemic sclerosis examined the effect of TGF $\beta$ inhibitors [50]. Some researchers believe that anti-TGF $\beta$ therapy is most likely to be effective during the early stages of systemic sclerosis, before the development of irreversible tissue fibrosis [51]. In addition, the pathogenic effect of TGF $\beta$ in systemic sclerosis appears to vary among patients [51]. TGF $\beta$ expression is generally greater during early-stage disease active systemic sclerosis, but is weak or undetectable in patients with established skin fibrosis. This may explain the negligible effects of TGF $\beta$ inhibitors in some patients with systemic sclerosis. To examine the possible therapeutic benefits of a TGF $\beta 1$ inhibitor in LN, we treated NZB/W mice with a TGF $\beta 1$ antagonist (SB431542). This inhibitor markedly decreased the renal expression of $\mathrm{C} 3$, $\mathrm{C} 3 \mathrm{aR}$, and other complement components in vivo. It is therefore possible that the administration of a TGF $\beta 1$ inhibitor to patients with LN may reduce the deposition of immune complexes, the inflammatory response, and renal fibrosis. Some evidence indicates that SB431542 may be a novel treatment for renal fibrosis [52]. Thus, SB431542 or another suitable TGF $\beta 1$ inhibitor may help to inhibit the deposition of complement components in the kidneys and provide effective treatment of LN. The usage of this approach for the treatment of $\mathrm{LN}$ requires further research.

Our research has several limitations. First, our studies of NZB/W mouse kidney tissues indicated increased C3 deposition as the disease progressed. However, because renal puncture is an invasive operation, we cannot track the deposition of $\mathrm{C} 3$ in human kidneys during the progression of LN. Thus, it is uncertain whether C3 gradually increases in the kidneys of LN patients as the disease progresses. Second, the source of the complement components we measured in the kidneys is not completely clear. Masanobu Miyazaki et al. [53] reported that C3 mRNA was observed in mesangial cells, glomerular epithelial cells, and Bowman's capsule in LN, which suggest that locally synthesized complement may be involved in tissue injury. In addition, it is found that $\mathrm{C} 1 \mathrm{q}$ produced by macrophages are closely related to the occurrence of LN [54]. Therefore, we speculate that complement components measured at the mRNA level may be from renal intrinsic cells or infiltrating inflammatory cells, and the complement components measured at the protein level may be from renal intrinsic cells, infiltrating inflammatory cells, or peripheral blood. Third, although we found a correlation of C3 and TGF $\beta 1$ expression, we did not establish a causal relationship. However, previous studies found that the combination of C3a and C3aR upregulated the expression of TGF $\beta 1$, and thereby promoted the progression of pulmonary fibrosis [55]. Nonetheless, further evidence is needed to confirm that $\mathrm{C} 3$ increases TGF $\beta 1$ expression in patients with $\mathrm{LN}$.

\section{Conclusions}

There were significantly greater levels of $\mathrm{C} 3$ and other complement pathway-related factors in the kidneys of patients with LN and NZB/W mice. C3 may participate in the pathogenesis of $\mathrm{LN}$ and contribute to albuminuria. TGF $\beta 1$ promotes the synthesis of $\mathrm{C} 3$, and TGF $\beta 1$ inhibition may block the progression of $\mathrm{LN}$ by inhibiting the synthesis of $\mathrm{C} 3$ and other complement components.

\footnotetext{
Abbreviations

ACR: American College of Rheumatology; C1: Complement C1; C3: Complement C3; C3aR1: Complement C3a receptor 1;

C5aR1: Complement C5a receptor 1; CR3: Complement component 3 receptor 3; CR4: Complement component 3 receptor 4; ECM: Extracellular matrix; ELISA: Enzyme-linked immunosorbent assay; FBS: Fetal bovine serum; FPR: Formyl peptide receptor; GO: Gene Ontology; KEGG: Kyoto Encyclopedia of Genes and Genomes; LN: Lupus nephritis; PBMC: Peripheral blood mononuclear cell; PDGF-B: Platelet-derived growth factor B; qPCR: Real-time quantitative PCR; SLE: Systemic lupus erythematosus; SLEDAI: SLE Disease Activity Index; TGF $\beta$ : Transforming growth factor- $\beta$; TLR9: Toll-like receptor 9
} 


\section{Supplementary Information}

The online version contains supplementary material available at https://doi. org/10.1186/s13075-021-02605-9.

Additional file 1: Supplementary Table S1. Clinical data of study subjects.

Additional file 2: Supplementary Figure S1. Volcano plot of genes differentially expressed in NZB/W mice (top) and patients with LN (bottom). Each point represents a gene that was detectable in both groups. Red point: upregulated genes; green point: downregulated genes.

Additional file 3: Supplementary Figure S2. Enrichment and $p$ values of upregulated KEGG pathways in the kidneys of LN patients. Dot size represents the number of genes enriched in the pathway, dot color represents the significance of each differential expression pathway, and dot position represents the enrichment degree of the pathway.

Additional file 4: Supplementary Table S2. Detailed information of $\mathrm{LN}$ related pathways.

Additional file 5: Supplementary Figure S3. Levels of $\mathrm{C} 1 \mathrm{q}$ and $\mathrm{C} 4$ in plasma of SLE patients. (A) C1q in SLE patients without $L N(N=38)$ and patients with $L N(N=28) .{ }^{*} p<0.05$. (B) C4 in SLE patients without LN (N $=76$ ) and patients with $L N(N=83)$. (C) Correlation of the protein levels of C1q and C3 in plasma ( $N=64$ ). (D) Correlation of the protein levels of C4 and C3 in plasma ( $=145)$

Additional file 6: Supplementary Figure S4. Immunohistochemical analysis of C3 in glomeruli (GLO) or renal tubules (TUB) of different classes of $L N$.

\section{Acknowledgements}

The authors thank all the patients who have participated in the study.

\section{Authors' contributions}

TL collected the clinical samples, contributed to experiments, and wrote the manuscript; MY performed experiments, did the statistical analysis, and created figures and tables; $Y X$ is involved in cell-culture; CJ performed mouse experiments; CL is involved in RT-qPCR experiments; ZJ provided clinical samples and analyzed clinical information; XW designed the study, analyzed data, and completed and revised the manuscript; all of the authors read and approved the manuscript.

\section{Funding}

This work was supported by Starting Fund of the First Hospital of Jilin University (04032690001) and Fund from the Department of Science and Technology of Jilin Province (20190201249JC).

\section{Availability of data and materials}

The datasets used and/or analyzed during the current study are available from the corresponding author on reasonable request.

\section{Declarations}

Ethics approval and consent to participate

Ethical approval for this study was provided by the Institutional Medical Ethics Review Board of the First Hospital of Jilin University (reference number: 2017-087) and all procedures were in compliance with the Declaration of Helsinki.

\section{Consent for publication}

All authors agree to publish this research.

\section{Competing interests}

The authors declare that they have no competing interests.
Received: 17 March 2021 Accepted: 11 August 2021

Published online: 25 August 2021

\section{References}

1. Moroni G, Raffiotta F, Ponticelli C. Remission and withdrawal of therapy in lupus nephritis. J Nephrol. 2016;29(4):559-65. https://doi.org/10.1007/s4062 0-016-0313-6.

2. Jakes RW, Bae SC, Louthrenoo W, Mok CC, Navarra SV, Kwon N. Systematic review of the epidemiology of systemic lupus erythematosus in the AsiaPacific region: prevalence, incidence, clinical features, and mortality. Arthritis Care Res. 2012:64(2):159-68. https://doi.org/10.1002/acr.20683.

3. Ocampo-Piraquive V, Nieto-Aristizabal I, Canas CA, Tobon GJ. Mortality in systemic lupus erythematosus: causes, predictors and interventions. Expert Rev Clin Immunol. 2018;14(12):1043-53. https://doi.org/10.1080/1744666X.2 018.1538789.

4. Dumestre-Perard C, Clavarino G, Colliard S, Cesbron JY, Thielens NM. Antibodies targeting circulating protective molecules in lupus nephritis: Interest as serological biomarkers. Autoimmun Rev. 2018;17(9):890-9. https://doi.org/10.1016/j.autrev.2018.03.013.

5. Flores-Mendoza G, Sanson SP, Rodriguez-Castro S, Crispin JC, Rosetti F. Mechanisms of Tissue Injury in Lupus Nephritis. Trends Mol Med. 2018;24(4): 364-78. https://doi.org/10.1016/j.molmed.2018.02.003.

6. Morgan BP, Gasque P. Extrahepatic complement biosynthesis: where, when and why? Clin Exp Immunol. 1997;107(1):1-7. https://doi.org/10.1046/j.13 65-2249.1997.d01-890.x.

7. Zhou W, Marsh JE, Sacks SH. Intrarenal synthesis of complement. Kidney Int 2001;59(4):1227-35. https://doi.org/10.1046/j.1523-1755.2001.0590041227.x.

8. Camussi G, Tetta C, Mazzucco G, Vercellone A. The brush border of proximal tubules of normal human kidney activates the alternative pathway of the complement system in vitro. Ann N Y Acad Sci. 1983;420(1 Defined Immun): 321-4. https://doi.org/10.1111/j.1749-6632.1983.tb22219x.

9. Li X, Ding F, Zhang X, Li B, Ding J. The expression profile of complement components in podocytes. Int J Mol Sci. 2016;17(4):471. https://doi.org/10.33 90/ijms17040471.

10. Sahu A, Lambris JD. Structure and biology of complement protein C3, a connecting link between innate and acquired immunity. Immunol Rev. 2001:180(1):35-48. https://doi.org/10.1034/j.1600-065X.2001.1800103.x.

11. Delanghe JR, Speeckaert R, Speeckaert MM. Complement C3 and its polymorphism: biological and clinical consequences. Pathology. 2014;46(1): 1-10. https://doi.org/10.1097/PAT.0000000000000042.

12. Klos A, Wende E, Wareham K, Monk PN. International Union of Basic and Clinical Pharmacology. [corrected]. LXXXVII. Complement peptide C5a, C4a, and C3a receptors. Pharmacol Rev. 2013;65(1):500-43. https://doi.org/1 $0.1124 /$ pr.111.005223.

13. Zhou H, Hasni SA, Perez P, Tandon M, Jang SI, Zheng C, et al. miR-150 promotes renal fibrosis in lupus nephritis by downregulating SOCS1. J Am Soc Nephrol. 2013;24(7):1073-87. https://doi.org/10.1681/ASN.2012080849.

14. Yuan $Y$, Yang M, Wang K, Sun J, Song L, Diao $X$, et al. Excessive activation of the TLR9/TGF-beta1/PDGF-B pathway in the peripheral blood of patients with systemic lupus erythematosus. Arthritis Res Ther. 2017;19(1):70. https:// doi.org/10.1186/s13075-017-1238-8.

15. Gionanlis L, Alexopoulos E, Papagianni A, Leontsini M, Memmos D. Fibrotic mechanisms in idiopathic rapidly progressive glomerulonephritis: the role of TGF-beta1 and C5b-9. Ren Fail. 2008;30(2):239-46. https://doi.org/10.1080/ 08860220701804979

16. Floege J, Ostendorf T, Janssen U, Burg M, Radeke HH, Vargeese C, et al. Novel approach to specific growth factor inhibition in vivo: antagonism of platelet-derived growth factor in glomerulonephritis by aptamers. Am J Pathol. 1999:154(1):169-79. https://doi.org/10.1016/S0002-9440(10)65263-7.

17. Hu HH, Chen DQ, Wang YN, Feng YL, Cao G, Vaziri ND, et al. New insights into TGF-beta/Smad signaling in tissue fibrosis. Chem Biol Interact. 2018;292: 76-83. https://doi.org/10.1016/j.cbi.2018.07.008.

18. Phan SH. Genesis of the myofibroblast in lung injury and fibrosis. Proc Am Thorac Soc. 2012:9(3):148-52. https://doi.org/10.1513/pats.201201-011AW.

19. Bonner JC. Regulation of PDGF and its receptors in fibrotic diseases. Cytokine Growth Factor Rev. 2004;15(4):255-73. https://doi.org/10.1016/j. cytogfr.2004.03.006.

20. Gu H, Mickler EA, Cummings OW, Sandusky GE, Weber DJ, Gracon A, et al. Crosstalk between TGF-beta1 and complement activation augments epithelial injury in pulmonary fibrosis. FASEB J. 2014;28(10):4223-34. https:// doi.org/10.1096/fj.13-247650. 
21. Hochberg MC. Updating the American College of Rheumatology revised criteria for the classification of systemic lupus erythematosus. Arthritis Rheum. 1997;40(9):1725. https://doi.org/10.1002/art.1780400928.

22. Weening JJ, D'Agati VD, Schwartz MM, Seshan SV, Alpers CE, Appel GB, et al. The classification of glomerulonephritis in systemic lupus erythematosus revisited. Kidney Int. 2004;65(2):521-30. https://doi.org/10.1111/j.1523-1755.2 004.00443.x.

23. Berthier CC, Bethunaickan R, Gonzalez-Rivera T, Nair V, Ramanujam M, Zhang W, et al. Cross-species transcriptional network analysis defines shared inflammatory responses in murine and human lupus nephritis. J Immunol. 2012;189(2):988-1001. https://doi.org/10.4049/jimmunol.1103031.

24. Liangzhong Xu WY. Criteria for judging immunohistochemical reactions. China Oncol. 1996;6(4):2.

25. Yuan Y, Zhao L, Ma N, Ye Z, Jiang Z, Chu C. Up-regulated Complement 3 Production by Toll-like receptor 9/ Transforming Growth Factor-Beta 1/ Complement 3 Pathway in Whole Blood Cells of Lupus Thrombocytopenia. Arch Rheumatol. 2017;32(4):275-83. https://doi.org/10.5606/ArchRheuma tol.2017.6279.

26. Bao L, Osawe I, Puri T, Lambris JD, Haas M, Quigg RJ. C5a promotes development of experimental lupus nephritis which can be blocked with a specific receptor antagonist. Eur J Immunol. 2005;35(8):2496-506. https:// doi.org/10.1002/eji.200526327.

27. Bao L, Osawe I, Haas M, Quigg RJ. Signaling through up-regulated C3a receptor is key to the development of experimental lupus nephritis. J Immunol. 2005;175(3):1947-55. https://doi.org/10.4049/jimmunol.175.3.1947.

28. Abbate M, Zoja C, Corna D, Rottoli D, Zanchi C, Azzollini N, et al. Complement-mediated dysfunction of glomerular filtration barrier accelerates progressive renal injury. J Am Soc Nephrol. 2008;19(6):1158-67. https://doi.org/10.1681/ASN.2007060686.

29. Ye J, Qian Z, Xue M, Liu Y, Zhu S, Li Y, et al. Aristolochic acid I aggravates renal injury by activating the $\mathrm{C} 3 \mathrm{a} / \mathrm{C} 3 \mathrm{aR}$ complement system. Toxicol Lett. 2019;312:118-24. https://doi.org/10.1016/j.toxlet.2019.04.027.

30. Ricklin D, Reis ES, Mastellos DC, Gros P, Lambris JD. Complement component C3 - The "Swiss Army Knife" of innate immunity and host defense. Immunol Rev. 2016;274(1):33-58. https://doi.org/10.1111/imr.12500.

31. Birmingham DJ, Hebert LA. The Complement System in Lupus Nephritis. Semin Nephrol. 2015;35(5):444-54. https://doi.org/10.1016/j.semnephrol.201 5.08.006.

32. Liu J, Xie J, Zhang X, Tong J, Hao X, Ren H, et al. Serum C3 and Renal Outcome in Patients with Primary Focal Segmental Glomerulosclerosis. Sci Rep. 2017;7(1):4095. https://doi.org/10.1038/s41598-017-03344-1.

33. Gonzalo-Gil E, Garcia-Herrero C, Toldos O, Usategui A, Criado G, Perez-Yague $\mathrm{S}$, et al. Microthrombotic Renal Vascular Lesions Are Associated to Increased Renal Inflammatory Infiltration in Murine Lupus Nephritis. Front Immunol. 2018;9:1948. https://doi.org/10.3389/fimmu.2018.01948.

34. Nisihara RM, Magrini F, Mocelin V, Messias-Reason IJ. Deposition of the lectin pathway of complement in renal biopsies of lupus nephritis patients. Hum Immunol. 2013;74(8):907-10. https://doi.org/10.1016/j.humimm.2013. 04.030.

35. Trouw LA, Pickering MC, Blom AM. The complement system as a potential therapeutic target in rheumatic disease. Nat Rev Rheumatol. 2017;13(9):53847. https://doi.org/10.1038/nrrheum.2017.125.

36. Kelly RH, Carpenter AB, Sudol KS, Jagarlapudi SP, Manzi S. Complement C3 fragments in urine: detection in systemic lupus erythematosus patients by western blotting. Appl Theoretical Electrophoresis. 1993;3(6):265-9.

37. Ricklin $D$, Hajishengallis $G$, Yang K, Lambris JD. Complement: a key system for immune surveillance and homeostasis. Nat Immunol. 2010;11(9):785-97. https://doi.org/10.1038/ni.1923.

38. Mizuno M, Blanchin S, Gasque P, Nishikawa K, Matsuo S. High levels of complement C3a receptor in the glomeruli in lupus nephritis. Am J Kidney Dis. 2007:49(5):598-606. https://doi.org/10.1053/j.ajkd.2007.02.271.

39. Thielens NM, Tedesco F, Bohlson SS, Gaboriaud C, Tenner AJ. C1q: A fresh look upon an old molecule. Mol Immunol. 2017:89:73-83. https://doi.org/1 0.1016/j.molimm.2017.05.025.

40. Macedo AC, Isaac L. Systemic Lupus Erythematosus and Deficiencies of Early Components of the Complement Classical Pathway. Front Immunol. 2016;7: 55.

41. Taylor PR, Carugati A, Fadok VA, Cook HT, Andrews M, Carroll MC, et al. A hierarchical role for classical pathway complement proteins in the clearance of apoptotic cells in vivo. J Exp Med. 2000;192(3):359-66. https://doi.org/10.1 084/jem.192.3.359.
42. Miura-Shimura Y, Nakamura K, Ohtsuji M, Tomita H, Jiang Y, Abe M, et al. C1q regulatory region polymorphism down-regulating murine c1q protein levels with linkage to lupus nephritis. J Immunol. 2002;169(3):1334-9. https://doi.org/10.4049/jimmunol.169.3.1334.

43. Manderson AP, Botto M, Walport MJ. The role of complement in the development of systemic lupus erythematosus. Annu Rev Immunol. 2004; 22(1):431-56. https://doi.org/10.1146/annurev.immunol.22.012703.104549.

44. Martin M, Blom AM. Complement in removal of the dead - balancing inflammation. Immunol Rev. 2016;274(1):218-32. https://doi.org/10.1111/ imr.12462.

45. Nauta AJ, Trouw LA, Daha MR, Tijsma O, Nieuwland R, Schwaeble WJ, et al. Direct binding of $\mathrm{Clq}$ to apoptotic cells and cell blebs induces complement activation. Eur J Immunol. 2002;32(6):1726-36. https://doi.org/10.1002/1 521-4141(200206)32:6<1726::AID-IMMU1726>3.0.CO;2-R.

46. Mosaad YM, Hammad A, Fawzy Z, El-Refaaey A, Tawhid Z, Hammad EM, et al. C1q rs292001 polymorphism and C1q antibodies in juvenile lupus and their relation to lupus nephritis. Clin Exp Immunol. 2015;182(1):23-34. https://doi.org/10.1111/cei.12666.

47. Kim H, Kim T, Kim M, Lee HY, Kim Y, Kang MS, et al. Activation of the alternative complement pathway predicts renal outcome in patients with lupus nephritis. Lupus. 2020;29(8):862-71. https://doi.org/10.1177/096120332 0925165

48. Hogasen AK, Hestdal K, Hogasen K, Abrahamsen TG. Transforming growth factor beta modulates $\mathrm{C} 3$ and factor $\mathrm{B}$ biosynthesis and complement receptor 3 expression in cultured human monocytes. J Leukoc Biol. 1995; 57(2):287-96. https://doi.org/10.1002/jb.57.2.287.

49. Rashad NM, El-Shabrawy RM, Said D, El-Shabrawy SM, Emad G. Serum Levels of Transforming Growth Factor Beta -1 (TGF-beta1) as An Early No Invasive Marker for Diagnosis of Lupus Nephritis in Systemic Lupus Erythematosus Patients. Egypt J Immunol. 2019;26(1):31-42.

50. Denton CP, Merkel PA, Furst DE, Khanna D, Emery P, Hsu VM, et al. Recombinant human anti-transforming growth factor betal antibody therapy in systemic sclerosis: a multicenter, randomized, placebo-controlled phase I/II trial of CAT-192. Arthritis Rheum. 2007;56(1):323-33. https://doi. org/10.1002/art.22289.

51. Varga J, Pasche B. Antitransforming growth factor-beta therapy in fibrosis: recent progress and implications for systemic sclerosis. Curr Opin Rheumatol. 2008;20(6):720-8. https://doi.org/10.1097/BOR.0b013e32830e4 8e8.

52. Mori Y, Ishida W, Bhattacharyya S, Li Y, Platanias LC, Varga J. Selective inhibition of activin receptor-like kinase 5 signaling blocks profibrotic transforming growth factor beta responses in skin fibroblasts. Arthritis Rheum. 2004;50(12):4008-21. https://doi.org/10.1002/art.20658.

53. Miyazaki M, Abe K, Koji T, Furusu A, Ozono Y, Harada T, et al. Intraglomerular C3 synthesis in human kidney detected by in situ hybridization. J Am Soc Nephrol. 1996;7(11):2428-33. https://doi.org/10.1681/ASN.V7112428.

54. Thanei S, Trendelenburg M. Anti-C1q autoantibodies from patients with systemic lupus erythematosus induce C1q production by macrophages. J Leukoc Biol. 2017;101(2):481-91. https://doi.org/10.1189/jlb.3A1215-535R.

55. Gu H, Fisher AJ, Mickler EA, Duerson F 3rd, Cummings OW, Peters-Golden $\mathrm{M}$, et al. Contribution of the anaphylatoxin receptors, C3aR and C5aR, to the pathogenesis of pulmonary fibrosis. FASEB J. 2016;30(6):2336-50. https://doi. org/10.1096/fj.201500044.

\section{Publisher's Note}

Springer Nature remains neutral with regard to jurisdictional claims in published maps and institutional affiliations.

\section{Ready to submit your research? Choose BMC and benefit from:}

- fast, convenient online submission

- thorough peer review by experienced researchers in your field

- rapid publication on acceptance

- support for research data, including large and complex data types

- gold Open Access which fosters wider collaboration and increased citations

- maximum visibility for your research: over $100 \mathrm{M}$ website views per year

At $\mathrm{BMC}$, research is always in progress.

Learn more biomedcentral.com/submissions 